\title{
Literature Review of Taoism Dress Culture in China
}

\author{
Rong Yang ${ }^{1} \&$ Xiaoming Yang ${ }^{1}$ \\ ${ }^{1}$ College of Humanities, Donghua University, Songjiang, Shanghai, China \\ Correspondence: Xiaoming Yang, College of Humanities, Donghua University, Songjiang, Shanghai, 201620, \\ China. E-mail: ynide@sina.com
}

Received: November 2, 2019

Accepted: November 19, 2019 Online Published: December 31, 2019

doi:10.5539/ass.v16n1p49

URL: https://doi.org/10.5539/ass.v16n1p49

\begin{abstract}
Religious dress is a special kind of dress, which often embodies the thoughts and cultural ideas of a certain religion, but it is also likely to show the deeply cultural deposits of a certain national culture. Taoist clothing is a kind of clothing and accessories with obvious Taoism cultural connotation formed by absorbing, integrating and extending Taoism doctrines on the basis of Chinese traditional dress, which is of great significance to study of Chinese traditional culture and worth in-depth study in further.
\end{abstract}

Keywords: Taoism, dress culture, literature review

Ancient Chinese traditional clothing is not only a simple item to wear, but also a form of national culture carrier and representation. The cultural contents contained in traditional clothing, as well as the elements of clothing thought, technology and aesthetics, it can surpass The Times and become an important new resource of contemporary and even future clothing culture. But generally speaking, there are still many gaps in the study of ancient Chinese costumes. For example, there is a lack of specific and specific systematic research on religious clothing. Religious dress is a special kind of dress, which often embodies the thoughts and cultural ideas of a certain religion, but it is also likely to show the deeply cultural deposits of a certain national culture. Taoist clothing is a kind of clothing and accessories with obvious Taoism cultural connotation formed by absorbing, integrating and extending Taoism doctrines on the basis of Chinese traditional dress, which is of great significance to study of Chinese traditional culture.

At present, the collation and study of Taoism dress culture are not systematic, comprehensive and in-depth. Most of the research results are based on the scientific system in ancient books and documents to sort out the appearance of Taoism dress, such as Tian Chengyang's "Taoism dress I", "Taoism dress II" and Zhou Gaode's "Taoist costumes". Only a few scholars from the perspective of culture and aesthetics to analyze connotation, such as Li Yi's "Study on Taoist dress aesthetics" Li pei's "Taoist costume aesthetic thoughts of Zhang Wanfu", etc., However, there are few in-depth research achievements in comprehensive research, especially from the perspective of science and technology, philosophy and cultural value.

Domestic scholars focus on the following aspects:

\section{Research on Taoism Dress's Thought}

The scholars have made a brief introduction to Taoism dress: Tian Chengyang's "Taoism dress I", "Taoism dress II" and Zhou Gaode's "Taoist costumes". Lu Xiujing summarized and reformed Taoism during the Liu Song Dynasties, and established the new Taoism dress. After that, it was gradually renovated. By the end of the southern and Northern Dynasties, a complete set of costume ritual was basically formed. On this basis, the existing Taoist costumes are briefly classified. Both of them emphasize that Taoism is very cautious in wearing its clothes, regardless of the Taoist school. It is considered that Taoist dress is a kind of Taoism prestige, and Taoism prestige is a criterion to regulate Taoism etiquette and behavior. There is a set of commandments for wearing. However, these early studies did not give a specific introduction to the evolution of the form of Taoism dress.

Other studies also reflect the connotation of Taoist clothing thought:

\subsection{In the Research of Clothing Design}

In Lu Xia's article "on the influence of Taoist culture on the pattern of traditional clothing", she believes that the formation of some patterns in traditional costumes is influenced by Yin and Yang, Eight Diagrams and five 
elements in Taoism. They are a kind of fusion of Taoism thought and dress culture ( $\mathrm{Lu}, 2013, \mathrm{p}$. 47).

\subsection{In the Research of Clothing Color}

Tian Xiaoying's "Research on the color symbols and aesthetics of Yongcheng". Through the female immortal clothing color and design symbols of religious aesthetic cognition to emphasize the ideological and cultural connotation of Taoist clothing. "In the color system of Taoism," she said, "Qing" belongs to Yin, an image of mystery and Yin. The color image of "Qing" conforms to the inner image crystallization of religious experience and aesthetic ideal of Taoism culture, and is the expression of the innate truth and the symbol of eternal road and its own meaning of Taoist goddess dress in accordance with nature and approaching perfection. This is not only Taoism's cultural inheritance of Chinese color design symbols, but also a hidden manifestation of national subconscious in religious divinity. From the perspective of cultural ideology, it rationally improves the feminine status on the basis of the harmony between Yin and Yang, and enriches and strengthens the aesthetic origin of Yin and softness, emptiness and nature of Taoism. In the process of expressing the image of "purple", the color context and cultural aesthetics of Taoism are important components. "Purple" image is not a form and representation, but a design idea and religious life experience that leads Taoist divinity to prominence and presence through visual "restatement". It can be seen that there have been some research results on the shape, system and color of Taoist costumes, but those are still a lack of research on the overall structural logic and constructional ethics of Taoist costumes (Tian, 2012, pp. 78-82).

\subsection{In the Research of Religious Symbols in Clothing}

In Jiang Sheng's article "the ethical value symbols of Taoism dress", from the perspective of the theological ethical function of Taoism dress, talks about the significance and value of Taoism dress as religious symbols, from the ethical tradition of Chinese costumes to the two levels of Taoism dress as Taoist symbols, and then stresses the significance of Taoism dress for the maintenance of ethical order of Taoism and the deification of human recognition of ethical norms. Clothing is regarded as a kind of intuitionistic ethical symbol media used by Taoism. This is of great significance to the study of Taoism dress, because costumes are not only the direct and concrete expression of Taoism dress, but also an important tool to maintain the internal system of Taoism. This paper provides a lot of strong evidence for the study of Taoist culture in Taoism dress (Jiang, 1995, pp. 118-121).

In addition, the cultural and ideological aspects of Taoist costumes and ancient Chinese traditional costumes also influence each other. In the Tang and Song Dynasties, Taoist clothing has become the common clothing of secular people. In this aspect, the academic circles take the literati and the secular people wearing the Taoist clothing as the object, and take the influence of the Taoist clothing secularization on the social culture at that time and the connotation of the clothing thought as the research content. Zhang Zhenqian's paper "An analysis of the phenomenon of literati officials wearing Taoism dress in the Northern Song Dynasty". The social and cultural phenomena of the literati in the Northern Song Dynasty reflected the further secularization of Taoism. This secularized Taoism, in turn, has become a source of nourishment for literati's ideology and life style. In the Northern Song Dynasty, scholars often compared Taoism dress with official uniform, showing their yearning for Taoism dress and its contained leisurely, self-adaptive and carefree life, which is the reference, absorption and transformation of the inherent religious meaning of Taoism dress (Zhang, 2010, pp. 93-105). In Wu Yu's paper "A study on the wearing of Taoism dress by secular people in Tang and Song Dynasties", it is proposed that the secular people selectively absorbed the patterns and symbolic meanings of Taoism dress, weakened the religious significance of Taoism dress, and gave it a very secular symbolic significance. At the same time, the secular people wearing Taoism dress are also restricted by the national public opinion clothing system and etiquette system. These studies are of great significance for us to understand the influence of secularization of Taoism dress on social culture. However, there is no systematic study on the characteristics, occasions and constraints of secular people's wearing Taoism dress (Wu, 2009, pp. 88-91).

\section{Research on Taoism Dress History}

In the aspect of Taoism dress history research, scholars have made some researches on the shape, system of Taoist clothing and its influence on ancient Chinese traditional clothing. As for the form of Taoist costume, the academic circles mostly take the ancient book "Daozang" as the model to describe the form of Taoist costume and its evolution process.

\subsection{From Han Dynasty to Wei, Jin, Southern and Northern Dynasties}

Sun Qi's "the establishment of the system of the middle ancient Taoist legal suit" made a detailed study of the form and the evolution of the system of the middle ancient Taoist legal suit from the Han Dynasty to the Wei, Jin and southern and Northern Dynasties. In his opinion, the development of the system of Taoism and Legalism in 
the Han and Tang Dynasties has gone through the following stages: "(1) the Wudoumi Daoist Church in the Han and Wei dynasties imitated the official uniform of the Han Dynasty, wearing the Jinxian crown, scarf, single clothes, leather belts, ribbon and tablet. After Zhang Lu descended to Cao Cao, he reformed, removed the ribbon and belt, and improved the JinXian crown to Xuanguan (scarf). Since then, the combination of single clothes, scarves is Wudoumi Daoist dress. (2) At the beginning of the fifth centuries, in the new Lingbao in the south, firstly, it put forward the idea that there are different Taoism costumes from the secular, and under the influence of Buddhism and seclusion culture, it created the Yellow Taoism costumes composed of scarves, coarse clothing, skirts and short embroidered cape. Later, the Shangqing also imitated the purple Taoism dress. (3) At the end of the northern and Southern Dynasties, with the emergence of the Taoist legal system, various kinds of legal uniforms from the old Tianshi, Lingbao, Shangqing Daoism and other different Confucian traditions were integrated into a unified system, and a hierarchical legal uniform system emerged, which laid the foundation of the Taoist legal uniform system in the Tang Dynasty. In this system, all the Daoism costumes are neatly divided into a crown, coarse clothing, skirts and short embroidered cape. The establishment of the system of legal dress of middle ancient Taoism is not only a problem in the history of clothing, but also a side of the transformation of middle ancient Taoism. It is of great significance to the study of the following Taoist costumes and the evolution of Chinese traditional costumes (Sun, 2016, pp. 69-94).

\subsection{Tang and Song Dynasties}

Lin Xilang's paper "A study of Taoist dress system in Tang Dynasty", he sorted out the Taoist dress system in Tang Dynasty and believed that Taoism had established a relatively perfect dress system in Tang Dynasty, including the celestial dress system, the Taoist dress system, the dress system for wearing, taking off, storing and making legal clothes and so on (Lin). Wang Lina's "The evolution of female Taoist dress in Tang Dynasty", taking the female Taoists as the research object, she studied the shape and system of the Taoist dress in the Tang Dynasty, and summarized that the dress had undergone three changes: the initial shape was basically determined; the middle was given ideological meaning, showing doctrinal; the later thought solidified into body performance, showing the ceremony of giving the dress. This evolution not only reflects the development of Taoism itself, but also shows the interaction between Taoism and politics and society at that time (Wang, 2017, pp. 39-47).

\subsection{Jin and Yuan Dynasties}

Liu Ke's "A study on Taoist immortal costume", Taking the specific image of Lv Dongbin as an example, this paper explains the Taoist cultural connotation contained in the object. Through the image of Taoist immortals clothing to distinguish the identity of immortals. Before Lv Dongbin became the founder of Quanzhen Daoism. In terms of the nature of images, there are two kinds of images of Lv Dongbin in later ages: reclusive immortal and Quanzhen Daoism. Therefore, the paper discusses the characteristics of Taoist fairy costumes from the perspective of headscarf and Taoist clothing, taking Lv Dongbin as an example. Therefore, it is closely related to the change of clothes in the Song, Yuan and Ming dynasties. After it entered the ranks of Quanzhen founder, it showed a trend of stereotype and became a unique image style and iconic feature (Liu, 2012, pp. 100-101).

In addition, the study of this period also includes Dong Yingbo master's thesis, "Characteristics of men's clothing in Taoist grottoes of yuan dynasty in Longshan". Taiyuan longshan Yuan dynasty Taoist grotto of men clothing and decorations are analyzed, he thought that no matter from the development of the traditional clothing shape, or from the perspective of the clothing system of Taoism itself, Taiyuan longshan Yuan dynasty Taoist grotto's clothing mainly reflects in the system and the characteristics of the specific dress style two aspects: such as God of Daosim and fairy costumes inherited the basic shape of the upper and lower clothes of the previous generation, and the Taoism dress system formed in the Northern and Southern Dynasties, its a little change. The local style of 'shen dai' and other costumes inherited from the previous era, but the overall style changed a lot. Therefore, the characteristics of the era of male Taoism dress were development and change based on inheritance and reference (Dong, 2010).

\subsection{The Ming and Qing Dynasties and Modern Times}

Tian Chengyang's "Taoism dress I", "Taoism dress II" and Zhou Gaode's "Taoist costumes". These studies only make a simple classification from the original ancient books and the existing Taoist costumes.

\section{Research on Taoism Dress Aesthetics}

The religious aesthetic concepts and thoughts of patterns, colors and symbols in Taoist costumes have a profound influence on Chinese traditional costumes and culture. Tian Xiaoying's "Research on the color symbols and aesthetics of Yongcheng". Through the female immortal clothing color and design symbols of religious aesthetic cognition to emphasize the Taoist clothing aesthetic cultural connotation. In the color system of Taoism, "Qing" 
belongs to Yin, an image of mystery and Yin. The color image of "Qing" conforms to the inner image crystallization of religious experience and aesthetic ideal of Taoism culture, and is the expression of the innate truth and the symbol of eternal road and its own meaning of Taoist goddess dress in accordance with nature and approaching perfection. This is not only Taoism's cultural inheritance of Chinese color design symbols, but also a hidden manifestation of national subconscious in religious divinity. From the perspective of cultural ideology, it rationally improves the feminine status on the basis of the harmony between Yin and Yang, and enriches and strengthens the aesthetic origin of Yin and softness, emptiness and nature of Taoism. In the process of expressing the image of "purple", the color context and cultural aesthetics of Taoism are important components. "Purple" image is not a form and representation, but a design idea and religious life experience that leads Taoist divinity to prominence and presence through visual "restatement". However, the research object of the article is limited, and there is no overall study on the pattern of clothing, which cannot reflect the overall aesthetic thought of Taoist clothing (Tian, 2012, pp. 78-82).

There are also some studies on the beauty of Taoist costumes from the perspective of aesthetics. Li Yi's "A study on Taoist dress aesthetics", from the aesthetic point of view, this paper studies the beauty of Taoist culture embodied in Taoist costumes. This paper discusses LaoZi and ZhuangZi's natural ecological aesthetic thought of costumes, which is one of the two systems of Chinese costume aesthetic thought. LaoZi's aesthetics is the starting point of the history of Chinese costume aesthetics. The Taoist costume aesthetics represented by LaoZi and ZhuangZi is an important part of the study of Chinese costume culture. However, the difference between Taoist costume and Taoist costume written in the second half of the article remains to be studied. It holds that Taoist dress has rich cultural connotation and aesthetic value, but its dress aesthetic thought is different from Taoist dress aesthetic thought. Taoist costume aesthetics is based on non utilitarian aesthetics, while Taoist costume is more about the expression of religious aesthetic education connotation and ethical category ( $\mathrm{Li}, 2014$, pp. 109-110). Li pei's "Taoist dress aesthetic thought of Zhang Wangfu" is mainly a Taoist scholar represented by zhang wanfu in the tang dynasty. With wan-fu zhang put forward "temporary false cassock, random set teaching" ideas of religious clothing reflects the way scholars at that time to appreciate has not only confined to the itself for individual religious restrictions and specifications, but through the clothing aesthetic education so as to make more firm belief of inner seekers, Taoist costume carries ethical aesthetic connotation to alert itself. However, the article only takes the tang dynasty daofu as the representative, which is not systematic and comprehensive (Li, 2004, pp. 55-59).

Daoism clothing aesthetics carries the spirit of ancient Chinese traditional culture, expresses its virtue of indifference and purity, spiritual integrity and spiritual feelings of natural ecology, which plays a certain role in the current social atmosphere of luxury as beauty, and is of great significance for inheriting and carrying forward the excellent national clothing culture.

In addition, some cutting-edge research results of textile and costume archaeology can also be used for reference in the study of Taoist costume culture. For example, the technological part of ancient Chinese textile technology discussed in Li Qiang's research "On textile technology in ancient Chinese art works provides technical theories and methods" for the shape and craft of Taoist costumes; Xu Rui's "Some thoughts on the archaeological research of Han Dynasty's costumes" provides technical theories and methods for the origin, shape and connotation of early Taoist costumes; Wang Xiuling's "Silk fabrics unearthed in Dingling" gives a detailed description of the types, patterns, colors and materials of the Ming Dynasty's silk fabrics. These materials provide a reference for the study of the shape and system of the Ming Dynasty's Taoist costumes. Yan Jinsong's "Study on the costumes of the terracotta figures unearthed in the tombs of the Song Dynasty in Chengdu" takes the costumes of the terracotta figures unearthed in the tombs of the Song Dynasty in Chengdu as well as the common people's General costumes are consistent with historical records, reflecting the social and historical features of Chengdu in the Song Dynasty. But the Song Dynasty clothing is the inheritance to the Tang Dynasty clothing, has formed a set of relatively complete clothing and the clothing crown system. This provides a historical reference for the study of the history of Taoist costume and the shape of Taoist costume in Song Dynasty.

\section{References}

Dong, Y. B. (2010). Characteristics of men's clothing in Taoist grottoes of Yuan dynasty in Longshan (Master's Thesis of Shanxi University).

Jiang, S. (1995). The ethical value symbols of Taoism dress. Chinese Classics Culture, (4), 118-121.

Li, P. (2004). On Zhang Wanfu's Costume Aesthetic Thoughts. Journal of Sichuan University (Philosophy and Social Science Edition), (3), 55-59. https://doi.org/10.3969/j.issn.1006-0766.2004.03.012 
Li, Y. (2014). A study on Taoist dress aesthetics. Art Research, (3), 109-110.

Lin, X. L. (2004). A study of Taoist dress system in Tang Dynasty. Guizhou Social Sciences, (4), 101-103.

Liu, K. (2012). Research on Xianzhen Dress of Taoism: Take Lü Dongbin for Example. Art \& Design, (5), $100-101$

$\mathrm{Lu}, \mathrm{X}$. (2013). On the influence of Taoist culture on the pattern of traditional clothing. Modern Decoration Theory, (2), 47.

Sun, Q. (2016). The establishment of the system of the middle ancient Taoist legal suit. Literature History, (4), 69-94.

Tian, X. Y. (2012). The aesthetic features and symbolic analysis of color of Taoist fairy dress in Rong fairyland. Journal of Zhoukou Normal University, 29(6), 78-82. https://doi.org/10.3969/j.issn.1671-9476.2012.06.021

Wang, L. N. (2017). The evolution of female Taoist dress in Tang Dynasty. History Teaching, (3), 39-47.

Wu, Y. (2009). On the Secular People Dressing Daoist's Clothes (道服) in the Tang and Song Dynasties. Academic Journal of Jinyang, (5), 88-91. https://doi.org/10.3969/j.issn.1000-2987.2009.05.017

Zhang, Z. Q. (2010). An Exposition and Analysis of the Phenomenon of Literati and Scholar-officials' Putting on the Taoist Robes in the Northern Song Dynasty. Studies in World Religions, (4), 93-105. https://doi.org/10.3969/j.issn.1000-4289.2010.04.011

\section{Copyrights}

Copyright for this article is retained by the author(s), with first publication rights granted to the journal.

This is an open-access article distributed under the terms and conditions of the Creative Commons Attribution license (http://creativecommons.org/licenses/by/4.0/). 